\title{
Effect of Activated Variations Carbon From Oil Palm Empty Fruit Bunch To Solar Cell Efficiency p-n Junction Layer $\mathrm{Cu}_{2} \mathrm{O}$ - $\mathrm{TiO}_{2}$
}

\author{
Saparudin $^{\mathrm{a}, 1}$, Rahmawati ${ }^{\mathrm{a}, 2^{*}}$, T. Andi Fadly ${ }^{\mathrm{a}, 3}$ \\ ${ }^{a}$ Universitas Samudra, Jalan Prof. Syarief Thayeb, Kota Langsa and 24416, Indonesia \\ ${ }^{1}$ saparudin8731@gmail.com; ${ }^{2}$ rahmawati@unsam.ac.id*; 3andifadly@unsam.ac.id \\ * corresponding author
}

Article history:

Accepted

Keywords:

solar cell

composite

activated carbon

p-n junction

$\mathrm{CuO}_{2}-\mathrm{TiO}_{2}$

\begin{abstract}
Research about influence effect of activated activated carbon from oil palm empty fruit bunch to solar cell efficiency p-n junction layer $\mathrm{Cu}_{2} \mathrm{O}$ $\mathrm{TiO}_{2}$ and direct of sunlight. The layer of $\mathrm{Cu}_{2} \mathrm{O}$ formed from copper $(\mathrm{Cu})$ burned with temperature $550{ }^{\circ} \mathrm{C}$ in 100 minutes. The solar cells are made with $\mathrm{TiO}_{2}$ layer composed of activated carbon from oil palm empty fruit bunch of $0 \%, 10 \%, 15 \%$, dan $20 \%$. The parameters of the solar cell can be obtained by measuring the short circuit $\left(\mathrm{I}_{\mathrm{sc}}\right)$, voltage open circuit $\left(\mathrm{V}_{\mathrm{oc}}\right)$, maximum power and Fill Factor $(\mathrm{FF})$ with resitor value (R) 0-50 k $\Omega$. The composed of $\mathrm{TiO}_{2} /$ activated carbon from oil palm empty fruit bunch analyzed using X-Ray Diffraction (XRD) and and Fourier Transform Infrared (FTIR) Spectrocopy. As a result addition of activated carbon from oil palm empty fruit bunch to solar cell efficiency is increase in the value, voltage and efficiency of solar cells. The results of the measurement of the highest efficiency of solar cells using a sun simulator and sunlight are found in variations of activated carbon $20 \%$, with each efficiency values $0,043 \%$ and $0,0018 \%$.
\end{abstract}

Copyright (C) 2020 Politeknik Aceh Selatan. All rights reserved.

\section{Introduction}

One source of energy that can be utilized to be converted into electrical energy is solar radiation energy. The potential of solar radiation energy in Indonesia is very large, especially in areas that are crossed by the equator. The intensity of solar radiation in the area averaged $4.8 \mathrm{kWh} / \mathrm{m}^{2} / \mathrm{day}$ [1]. Solar cell devices can be used to convert solar radiation energy into electrical energy through the photovoltaic process. One of the metal oxide materials that can be used as a constituent of solar cells is Copper (I) Oxide $\left(\mathrm{Cu}_{2} \mathrm{O}\right)$. Copper (I) Oxide $\left(\mathrm{Cu}_{2} \mathrm{O}\right)$ has an energy gap of around $2.1 \mathrm{eV}$. The energy gap has an acceptable range of values for the conversion of solar radiation energy [2].

Nurhidayah in 2017 conducted research on the manufacture of $\mathrm{TiO}_{2}$ composite solar cells/graphite rosella flower extract produced solar cells with the highest efficiency reaching $0.003 \%$ [3]. Fadlly in 2018 conducted research on the characteristics of $\mathrm{I}-\mathrm{V} \mathrm{Cu} / \mathrm{Cu}_{2} \mathrm{O}$ solar cells using star fruit electrolytes, in that study the highest efficiency solar cells were found in $\mathrm{Cu} / \mathrm{Cu}_{2} \mathrm{O}-100$ samples with efficiency values reaching $2.84 \%$ [4]. Based on these studies, this article will examine the effect of variations in activated carbon from on the efficiency of $\mathrm{Cu}_{2} \mathrm{O}-\mathrm{TiO}_{2} \mathrm{p}$-n junction solar cells to broaden the analysis of solar cells in the hope of having high solar cell efficiency. The solar cell will be compared to a composite 
comparison of $\mathrm{TiO}_{2}$ with activated carbon from oil palm empty fruit bunch to get the best solar cell efficiency.

\section{Method}

\section{A. Material Preparation}

$\mathrm{Cu}_{2} \mathrm{O}$ coating plates will be produced from $\mathrm{Cu}$ plates with a size of $5 \mathrm{~cm} \times 2.5 \mathrm{~cm}$ through a thermal oxidation process at $550^{\circ} \mathrm{C}$ in 100 minutes [4]. While activated carbon from oil palm empty fruit bunch is produced through a chemical activation method, where the oil palm empty fruit bunch carbon is immersed using $3 \mathrm{M} \mathrm{H}_{2} \mathrm{PO}_{4}$ solution for 24 hours. Then the results of the marinade are filtered using filter paper and a neutralization process is carried out using $\mathrm{HCl}$ and distilled water. The process produces activated carbon from oil palm empty fruit bunch [5].

\section{B. Synthesis of TiO $\mathrm{O}_{2}$ Activated Carbon Composite Paste from Oil Palm Empty Fruit Bunch}

The manufacture of composite paste begins with the manufacture of polyvinyl alcohol (PVA) suspensions. In making a suspension, the PVA is stirred using a magnetic stirrer at a temperature of $80{ }^{\circ} \mathrm{C}$ for 30 minutes [6]. PVA functions as a binder in the manufacture of $\mathrm{TiO}_{2} /$ activated carbon composites from oil palm empty fruit bunch. Furthermore, to obtain the best composite results, $\mathrm{TiO}_{2}$ powder and activated carbon powder from oil palm empty fruit bunch variation in weight percentages as shown in table 1 .

Table 1. Percentage ratio of $\mathrm{TiO}_{2} /$ activated carbon composite from oil palm empty fruit bunch

\begin{tabular}{cccc}
\hline No & Sample & $\begin{array}{c}\mathbf{T i O}_{2} \\
(\mathbf{w . t \%})\end{array}$ & Activated Carbon (w.t\%) \\
\hline 1 & $\mathrm{TiO}_{2}-\mathrm{C} \mathrm{0 \%}$ & 80 & 0 \\
2 & $\mathrm{TiO}_{2}-\mathrm{C} 10 \%$ & 70 & 10 \\
3 & $\mathrm{TiO}_{2}-\mathrm{C} 15 \%$ & 65 & 15 \\
4 & $\mathrm{TiO}_{2}-\mathrm{C} 20 \%$ & 60 & 20 \\
\hline
\end{tabular}

After a comparison between $\mathrm{TiO}_{2}$ and activated carbon crushed using a mortar survived 10 minutes. Addition of PVA to the composite using a ratio of $1: 1$. Then stir homogeneously so that a $\mathrm{TiO}_{2} /$ activated carbon composite paste will form oil palm empty fruit bunch.

\section{ITO Glass Coating}

Homogeneous composite $\mathrm{TiO}_{2} /$ activated carbon paste from oil palm empty fruit bunch was deposited on ITO glass with doctor blade technique to form a thin layer [7]. The area of the ITO glass to be deposited is $4.5 \mathrm{~cm} \times 2.5 \mathrm{~cm}$. The prototype design of solar cells that have been deposited with $\mathrm{TiO}_{2} /$ activated carbon composites from oil palm empty fruit bunch is shown in Fig 1.

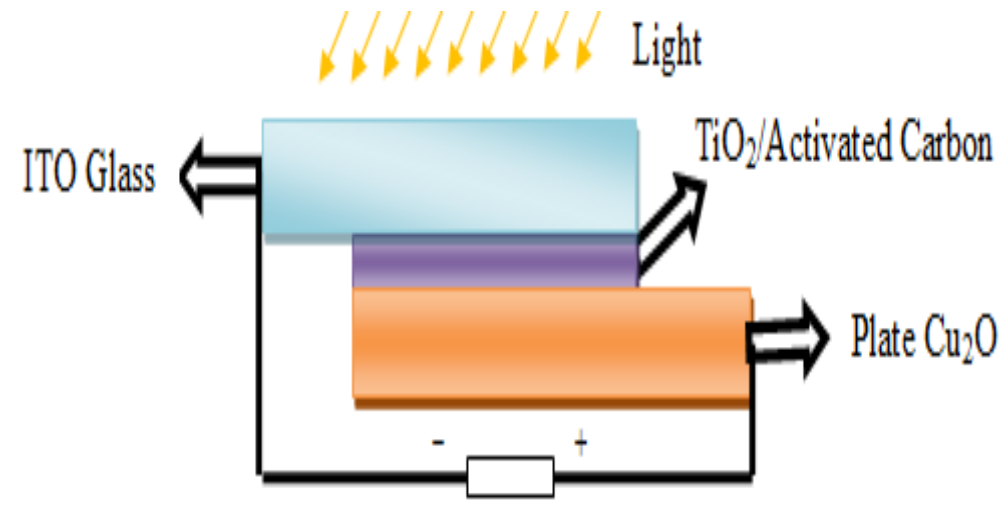

Fig 1. Prototype Design of Solar Cell 


\section{Data analysis method}

$\mathrm{TiO}_{2} /$ activated carbon composites from oil palm empty fruit bunch will be analyzed using X-ray Diffraction (XRD) to identify the formation of a composite between $\mathrm{TiO}_{2}$ and activated carbon from oil palm empty fruit bunch. Next, the Spectrocopy Fourier Transform Infrared (FTIR) test will be performed to support the XRD results. I-V characteristics of solar cells will be carried out using sun simulators and direct sunlight by measuring the parameters of the open circuit voltage $\left(\mathrm{V}_{\mathrm{oc}}\right)$ and short circuit current $\left(\mathrm{I}_{\mathrm{sc}}\right)$ with a resistance variation of $0-50 \mathrm{~K} \Omega$.

\section{Results and Discussion}

\section{A. Analysis XRD and FTIR}

The results of XRD analysis on $\mathrm{TiO}_{2}$ powder identified rutile phase using Match software with PDF number 96-900-7532. The phase peaks which have $\mathrm{TiO}_{2}$ are shown in Fig 2. In Fig 2 we see the peak intensity between carbon and $\mathrm{TiO}_{2}$, no new peaks are found, so that between $\mathrm{TiO}_{2}$ and activated carbon from oil palm empty fruit bunch can still be distinguished.

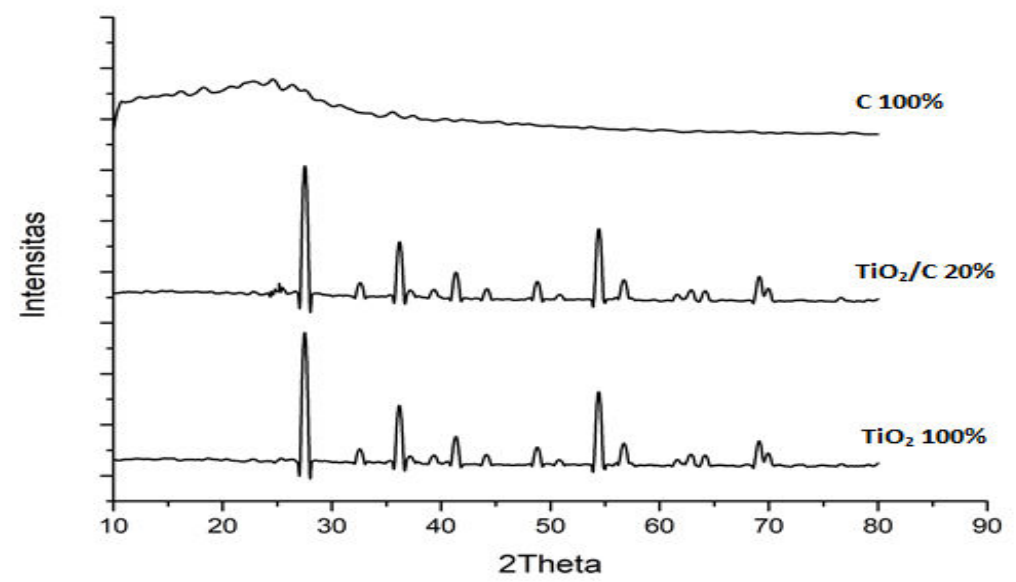

Fig 2. Analysis XRD

The results of the analysis of $\mathrm{TiO}_{2} /$ activated carbon composites from oil palm empty fruit bunch using FTIR spectroscopy are shown in Fig 3. The range of wave numbers used in the process is 4000-400 $\mathrm{cm}^{-1}$.

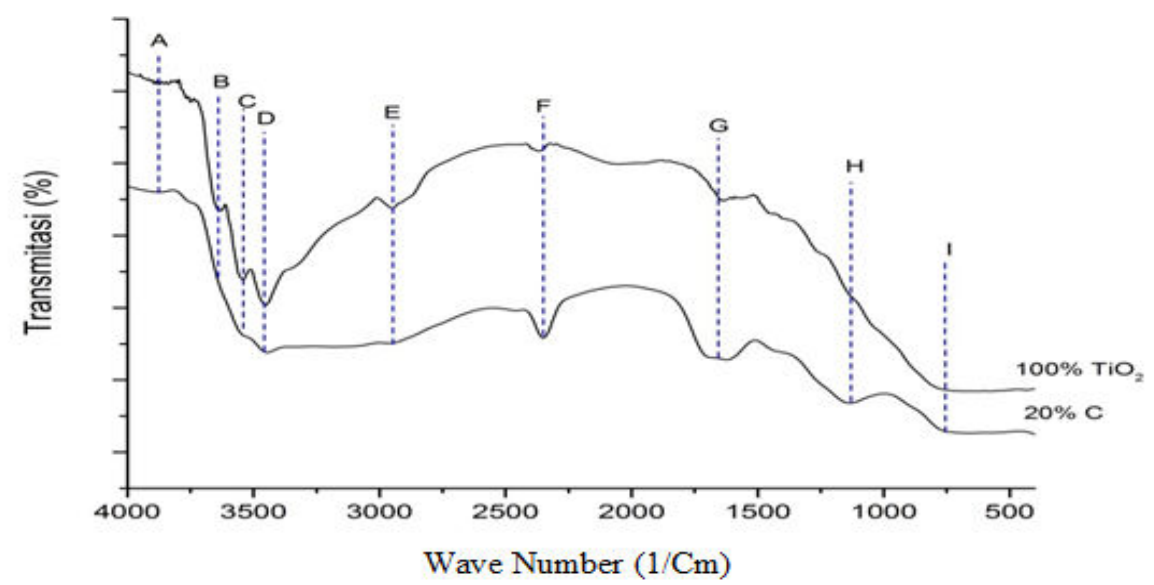

Fig 3. The FTIR composite spectroscopy of $\mathrm{TiO}_{2} /$ activated carbon from oil palm empty fruit bunch.

Based on the Fig 3, the infrared spectrum detected vibrations in bonds between atoms with their ideal state. At lines A, B, C, D E with wave numbers between $3760-3000 \mathrm{~cm}^{-1}$ is an $\mathrm{O}-\mathrm{H}$ stretching functional group originating from $\mathrm{H}_{2} \mathrm{O}$ [8]. E line with wave number $2858 \mathrm{~cm}^{-1}$ corresponds to group $\mathrm{C}-\mathrm{H}$. The $\mathrm{C}-\mathrm{H}$ group is thought to originate from the impurity of organic compounds trapped in activated carbon 
[9]. The peak of the active carbon spectrum at wave numbers $2353 \mathrm{~cm}^{-1}$ and $1701 \mathrm{~cm}^{-1}$ shown at lines $\mathrm{F}$ and $\mathrm{G}$ are functional group bonds $\mathrm{C}=\mathrm{O}$, wave number 1134 at line $\mathrm{H}$ refers to bonds $\mathrm{C}-\mathrm{O}$ [10]. While at line I with a wave number of $690 \mathrm{~cm}^{-1}$ is a functional group $\mathrm{O}-\mathrm{Ti}-\mathrm{O}$ [11]. Addition of activated carbon from oil palm empty fruit bunch $20 \%$ to $\mathrm{TiO}_{2}$ changes the peak of the spectrum. Based on the results of the FTIR graph, there is no functional group bond between $\mathrm{TiO}_{2}$ and activated carbon, so that it can be stated the formation of a composite.

\section{B. Characteristics of Solar Cell I-V}

Characteristics I-V are performed under direct sunlight conditions and using a sun simulator. Based on the measurement results of the open circuit voltage $\left(\mathrm{V}_{\mathrm{oc}}\right)$ and short circuit current $\left(\mathrm{I}_{\mathrm{sc}}\right)$, the maximum voltage $\left(\mathrm{V}_{\text {maks }}\right)$ and maximum current $\left(\mathrm{I}_{\text {maks }}\right)$ can be determined through the optimal power $\left(\mathrm{P}_{\text {out }}\right)$ of the current characteristic curve against the voltage $(\mathrm{I}-\mathrm{V})$. The characteristics of $\mathrm{I}-\mathrm{V}$ solar cells using sun simulator and sunlight are shown in Fig 4.

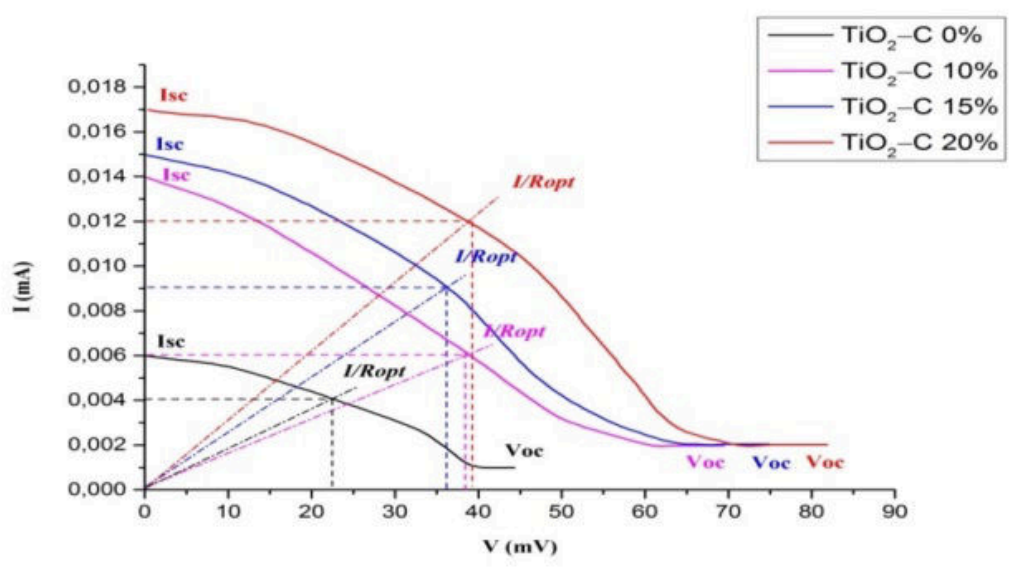

(a)

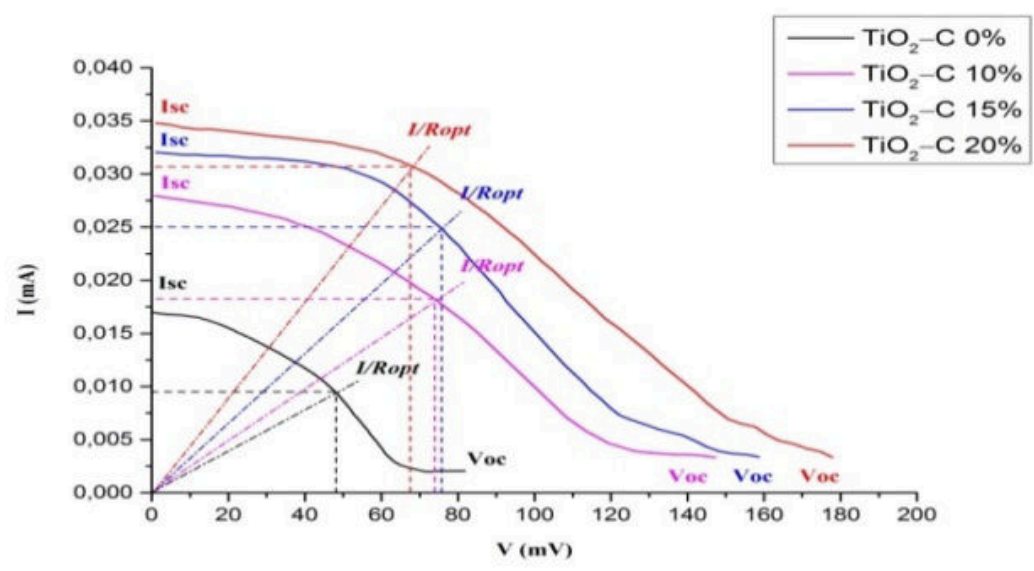

(b)

Fig 4. Curve I-V of solar cells (a) using a sun simulator, (b) using a sunlight 
Based on Fig 4 there is a change between current and voltage, where the highest $\mathrm{I}_{\mathrm{sc}}$ value is present when the solar cell is not given a load resistance. While the value of $\mathrm{V}_{\text {oc }}$ increases with increasing load placed on solar cells. The increasing value of the efficiency of solar cells is also influenced by the addition of activated carbon to the $\mathrm{TiO}_{2}$ composite. That is because activated carbon can help the absorption of electrons to solar cells to be more maximal [12].

Table 2. The characteristic value of I-V solar cells using a sun simulator

\begin{tabular}{lllllllll}
\hline Sample & $\begin{array}{l}\mathbf{V}_{\text {oc }} \\
(\mathbf{m V})\end{array}$ & $\begin{array}{l}\mathbf{I}_{\mathbf{s c}} \\
(\mathbf{m A})\end{array}$ & $\begin{array}{l}\mathbf{V}_{\text {maks }} \\
(\mathbf{m V})\end{array}$ & $\begin{array}{l}\mathbf{I}_{\text {maks }} \\
(\mathbf{m A})\end{array}$ & $\begin{array}{l}\mathbf{P}_{\text {in }} \\
(\mathbf{m W})\end{array}$ & $\begin{array}{l}\mathbf{P}_{\text {out }} \\
(\mathbf{m W})\end{array}$ & $\mathbf{F F}$ & $\begin{array}{l}\mathbf{H} \\
(\mathbf{\%})\end{array}$ \\
\hline $\mathrm{TiO}_{2}-\mathrm{C} 0 \%$ & 44,2 & 0,006 & 23 & 0,004 & 11,14 & 0,09 & 0,34 & 0,008 \\
$\mathrm{TiO}_{2}-\mathrm{C} 10 \%$ & 70 & 0,014 & 37,5 & 0,006 & 11,14 & 0,22 & 0,22 & 0,020 \\
$\mathrm{TiO}_{2}-\mathrm{C} 15 \%$ & 75 & 0,015 & 39 & 0,009 & 11,14 & 0,35 & 0,31 & 0,031 \\
$\mathrm{TiO}_{2}-\mathrm{C} 20 \%$ & 82,5 & 0,17 & 43 & 0,011 & 11,14 & 0,47 & 0,35 & 0,043 \\
\hline
\end{tabular}

The complete current and voltage values can be seen in Table 2 and Table 3. In Table 2 the highest efficiency of solar cells when using a sun simulator is found in the sample $\mathrm{TiO}_{2}-\mathrm{C} 20 \%$ by $0.043 \%$. In this sample the weight variation of $60 \% \mathrm{TiO}_{2}$ and $20 \%$ of oil palm empty fruit bunch activated carbon were used. Then the solar cells when using direct sunlight the highest efficiency values are also found in the sample $\mathrm{TiO}_{2}-\mathrm{C} 20 \%$ by $0.0018 \%$ as shown in Table 3 . The efficiency of solar cells using direct sunlight is much lower than the efficiency using the sun simulator test. This is due to the magnitude of the Pin value generated from sunlight. The power produced by sunlight reaches $830 \mathrm{~W} / \mathrm{m}^{2}$, while the power from the sun simulator is $9.9 \mathrm{~W} / \mathrm{m}^{2}$ [4].

Table 3. The characteristic value of I-V solar cells using a sunlight

\begin{tabular}{ccccccccc}
\hline Sample & $\begin{array}{c}\mathbf{V}_{\text {oc }} \\
(\mathbf{m V})\end{array}$ & $\begin{array}{c}\mathbf{I}_{\text {sc }} \\
(\mathbf{m A})\end{array}$ & $\begin{array}{c}\mathbf{V}_{\text {maks }} \\
(\mathbf{m V})\end{array}$ & $\begin{array}{c}\mathbf{I}_{\text {maks }} \\
(\mathbf{m A})\end{array}$ & $\begin{array}{c}\mathbf{P}_{\text {in }} \\
(\mathbf{m W})\end{array}$ & $\begin{array}{c}\mathbf{P}_{\text {out }} \\
(\mathbf{m W})\end{array}$ & $\mathbf{F F}$ & $\begin{array}{c}\boldsymbol{\eta} \\
(\mathbf{\%})\end{array}$ \\
\hline $\mathrm{TiO}_{2}-\mathrm{C} 0 \%$ & 105 & 0,014 & 53 & 0,009 & 933 & 0,45 & 0,30 & 0,0004 \\
$\mathrm{TiO}_{2}-\mathrm{C} 10 \%$ & 150 & 0,028 & 76 & 0,018 & 933 & 1,33 & 0,31 & 0,0012 \\
$\mathrm{TiO}_{2}-\mathrm{C} 15 \%$ & 162 & 0,032 & 70 & 0,025 & 933 & 1,75 & 0,33 & 0,0016 \\
$\mathrm{TiO}_{2}-\mathrm{C} 20 \%$ & 180 & 0,035 & 67 & 0,031 & 933 & 2,08 & 0,33 & 0,0018 \\
\hline
\end{tabular}

\section{Conclusion}

The results of the characteristics of I-V solar cells p-n junction layer of $\mathrm{Cu}_{2} \mathrm{O}$ composite $\mathrm{TiO}_{2} /$ activated carbon from oil palm empty fruit bunch that has been implemented can be summarized as follows:

1. The XRD results identified the $\mathrm{TiO}_{2}$ powder as a rutile phase and between the peak intensities of $\mathrm{TiO}_{2}$ and activated carbon from oil palm empty fruit bunch can still be distinguished.

2. Based on the results of characteristic data of $I-V$, the highest efficiency value is obtained in solar cells with $20 \%$ active carbon variation.

\section{References}

[1] Suhardi D. Prototipe Sel Surya Berbahan Tembaga Oksida (CuO) dan Seng Oksida ( $\mathrm{ZnO})$ dengan Dielektrikum $\mathrm{H}_{2} \mathrm{SO}_{4}$. Gamma. 2013;9:130-6.

[2] Oktaviani Y, Astuti. Sintesis Lapisan Tipis Semikonduktor dengan Bahan Dasar Tembaga (Cu) Menggunakan Chemical Bath Deposition. J Fis Unand. 2014;3(1):53-8. 
[3] Nurhidayah, Usna SRA, Suwarni, Afrianto MF, Faizar F. Pembuatan Sel Surya Tersensitasi Pewarna (SSTP) Lapisan $\mathrm{TiO}_{2} /$ Grafit Dari Ekstrak Kelopak Bunga Rosella, Beras Ketan Hitam, Dan Ubi Jalar Ungu. JoP. 2017;2(2):6-10.

[4] Fadlly TA, Fajriani, Hermawan T. Characteristic I-V Of Cu/ $\mathrm{Cu}_{2} \mathrm{O}$ Solar Cells With Belimbing Wuluh (Averrhoa bilimbi L.) Electrolyte Using Sun Simulator. J NeutrinoJurnal Fis dan Apl. 2018;11(1):6-10.

[5] Rosalina, Tedja T, Riani E, Sugiarti S. Pengaruh Aktivasi Fisika dan Kimia Arang Aktif Buah Bintaro Terhadap Daya Serap Logam Berat Krom. Biopropal Ind. 2016;7:35-45.

[6] Sembiring MAR, Pramono SH, Maulana E, Jurusan M, Elektro T, Elektro JT, et al. Pengaruh Variasi Ketebalan Titanium Dioksida $\left(\mathrm{TiO}_{2}\right)$ Terhadap Daya Keluaran Dye Sensitized Solar Cell ( DSSC ). In Malang; 2015. p. 1-6.

[7] Fahyuan HD, Samsidar, Farid F, Heriyanti, Napitupulu S, Pakpahan S. Disain Prototipe Sel Surya Dssc (Dye Sensitized Solar Cell) Lapisan Grafit/TiO 2 Berbasis Dye Alami. JoP. 2015;1:5-11.

[8] Wardiyati S, Fisli A, Dewi SH. Eliminasi Senyawa Azobenzene Pada Limbah Batik Menggunakan Nanokatalis $\mathrm{Fe}_{3} \mathrm{O}_{4} / \mathrm{SiO}_{2} / \mathrm{TiO}_{2}$ dan Sinar Matahari. MPI. 2017;11(1):69-76.

[9] Utubira Y, Wijaya K, Triyono, Sugiharto E. Preparation And Characterization Of $\mathrm{TiO}_{2}-\mathrm{Zeolite}$ And Its Application To Degrade Textille Wastewater By Photocatalytic Method. Indo J Chem. 2006;6(3):231-7.

[10] Wahyuningsih P, Yusri N, Hamdani. Characterization of Activated Carbon Prepared from Oil Palm Empty Fruit Bunch by Chemical Activation using Sulphuric Acid $\left(\mathrm{H}_{2} \mathrm{SO}_{4}\right)$. Proc 3Departement Mech Eng Fac Eng Univ Samudra. 2016;4.

[11] Karim S, Pardoyo, Subagiyo A. Sintesis dan Karakterisasi $\mathrm{TiO}_{2}$ Terdoping Nitrogen (N-Doped $\mathrm{TiO}_{2}$ ) dengan Metode Sol-Gel. J Sci Apllied Chem. 2016;19(2):63-7.

[12] Arsita $\mathrm{Y}$, Astuti. Sintesis Komposit $\mathrm{TiO}_{2} /$ Karbon Aktif Berbasis Bambu Betung (Dendrocalamus asper) dengan Menggunakan Metode Solid State Reaction. J Fis Unand. 2018;5(3):268-72. 